\title{
The Role of Mobile Phones in Developing Motivation through Reading Activities in English Language Learners ${ }^{1}$
}

El papel de los teléfonos móviles en el desarrollo de la motivación a través de actividades de lectura en aprendices de inglés.

\section{Roger Segura Arias ${ }^{2 *}$}

Universidad Nacional de Costa Rica

${ }^{1}$ Received: January 20th 2020/ Accepted: February 25th /2021

2 roger.segura.arias@una.ac.cr 


\section{Abstract}

This case study attempts to elucidate the effects of mobile phones as tools for teaching reading in fostering motivation in EFL students. Through qualitative research techniques, the researcher analyses the impact that the implementation of a set of activities in a reading techniques course has on second-year English language learners' motivation. Focus groups and questionnaires help gather the students' perceptions of their involvement, enjoyment, and investment; the atmosphere created during the implementation of the activities, and their overall experience. In conclusion, the ubiquity of cell phones provides advantages in the development of motivation towards learning English and in fostering independence.

Keywords: technology, mobile phones, motivation, reading activities, EFL

\section{Resumen}

Este estudio de caso intenta dilucidar los efectos de los teléfonos móviles como herramientas para la enseñanza de la lectura en fomentar la motivación en los estudiantes de inglés como lengua extranjera. Mediante el uso de técnicas de investigación cualitativa, el investigador analiza los efectos que tiene la implementación de un conjunto de actividades en un curso de técnicas de lectura sobre la motivación de los estudiantes de segundo año de inglés. Grupos focales y cuestionarios ayudan a reunir las percepciones de los estudiantes sobre su participación, disfrute e interés; el ambiente creado durante la implementación de las actividades y su experiencia en general. En conclusión, la ubicuidad de los teléfonos celulares proporciona ventajas en el desarrollo de la motivación para aprender inglés y para fomentar la independencia.

Palabras clave: tecnología, teléfonos móviles, motivación, actividades de lectura, EFL

\section{Resumo}

Este estudo de caso tenta dilucidar os efeitos que tem o uso dos telefones celulares como ferramentas para ensinar leitura para fomentar a motivação nos estudantes de EFL. Através do uso de técnicas qualitativas de pesquisa, o professor implementa um conjunto de atividades em um curso de técnicas de leitura para estudantes de inglês de segundo ano; grupos focais e questionários ajudam a reunir as percepções dos estudantes sobre a sua participação, disfrute e interesse; $\mathrm{o}$ ambiente criado durante a implementação das atividades e a sua experiência em geral. Em conclusão, a onipresença dos telefones celulares proporciona vantagens no desenvolvimento da motivação para aprender inglês e para fomentar a independência.

Palavras chave: tecnologia, telefones celulares, motivação, atividades de leitura, EFL 


\section{Introduction}

anguage teaching and learning is undergoing rapid changes, especially with the introduction of modern technology in pedagogy. Although the changes have occurred gradually, teachers have encountered challenges concerning accessibility and availability of resources and materials. One resource that has gained popularity are cell phones; it has eased common issues pertaining to the handiness of electronic devices. They are personal resources that can be used as part of the pedagogical mediation while promoting motivation. Hereof, students face various challenges when learning a foreign language; motivation has been noted to be essential when developing language proficiency. Ortega (2013) expressed that motivation is "the desire to initiate L2 learning and the effort employed to sustain it, and in lay terms we all understand it to be a matter of quantity (p.168). Motivation is an abstract construct that involves four aspects: "a goal, effortful behaviour, a desire to attain the goal and favourable attitudes toward the activity in question" (Gardner, 1985, as cited in Gass and Selinker, 2009, p. 426). Although students mainly develop motivation by themselves, teachers can promote tools, activities, and resources to motivate students in their classes. In this sense, technology may encourage learning by enhancing participation and engagement in classroom activities.

By using technology, educators can help students feel more comfortable while learning. By integrating cell phones, which has now become a part of daily life, it can also be essential in carrying out everyday tasks to develop a sense of pertinence. This study may make a significant contribution to the body of existing research by contextualizing the study to the Costa Rican higher education system, motivating other professors to leave behind concerns about the use of cell phones in the classroom, and by innovating to promote the students' learning and boost their linguistic competence. 


\section{Purpose}

This research aims to analyze the effects of cell phone-based reading activities on fostering motivation in second-year English teaching students at the Universidad Nacional, Brunca Extension. The study involves designing and implementing reading activities that include using cell phones as a critical element to facilitate learning. Also, the researcher gathers students' perceptions of the effectiveness of the given activities in enhancing motivation. Finally, a crucial purpose is to reflect on the impact that cell phone-based activities have in promoting motivation.

\section{Research Questions}

This research project aims to answer the following questions about the use of mobile technology in developing motivation in EFL students by implementing reading activities: What is the role of technology in an English language student's learning process? How can cell phone use as a learning tool help students feel motivated during reading activities? Why should language teachers include cell phone use in their reading activities?

\section{Literature Review}

\section{ESL teaching and technology}

Classroom technology integration brings many advantages when used purposefully by instructors. The modern student needs to prepare for an interconnected world, where technology is vital to achieving everyday tasks. "Social, political and economic changes are coming together with pedagogic changes at a breathtaking pace (Kress \& Pachler, 2007, p.7). In English language teaching and learning, technology has aided these processes by enabling access to materials and facilitating their use in education. The following summary presents a set of reasons for how technology can become the backbone of the integration of technology in the classroom, as presented by Hamilton (2015). First, classroom technology has two models: its instructional function, where teachers use it during whole-class or small-group interactions. A second model denotes the demonstration mode of technology; in this case, students control its use while teachers lead them. Another principal pivots around how learners acquire knowledge when they partake in learning, by discovering ideas, activating their schemata, and, most importantly, forming ways to share knowledge with peers (pp. 4-5). The type of technology integration used in the language classroom will be determined by the instructor, and the purpose that technology will be given in it. Another aspect that can 
shape how technology is employed is related to the types of technology available to the students.

\section{Mobile technology and teaching reading}

Reading is a crucial skill to develop in students in EFL instruction; it allows for exposure to authentic language while learners interact with new vocabulary, grammar structures, and mechanics. Reading requires active interaction between the reader and the text; its acquisition is imperative in developing language literacy; it is a dynamic and interactive process that allows the use of various skills, strategies, and background knowledge (Constantinescu, 2007, para. 3). Teaching reading strategies in English language classrooms is challenging; it is time-consuming and promotes engagement and motivation may be difficult. Innovative measures need to be applied in the classroom to productive learning engagement to improve the range and depth of processing, which can be unavailable to students in classrooms without technology use (Nettelbeck, 2005, p.31). In this sense, active interaction between the reader and the text may be achieved through innovation. Adding technology to the reading process can aid readers' engagement and promote learning.

In contrast, there are challenges to overcome when integrating cell phones in reading teaching and learning. "One such challenge, for example, surrounds the physicality of the devices: due to their small size, the amount of data that can be displayed at any one time and the ease with which it can be manipulated is limited" (Kress \& Pachler, 2007, p.12). Because cell phones are usually smaller devices, display capabilities and storage can be compromised, compared to tablets and laptop computers; such limitations need to be borne in mind when using mobiles as reading devices.

\section{Promoting motivation with technology in language teaching}

Besides the multiple benefits that technology provides in language teaching, technology's role in enhancing motivation is also worth examining. Ortega (2013) presented a comparison of three main dimensions of motivation; first, intensity refers to the effort with which people try to learn the language; enjoyment indicates the learner's feeling of pleasure while learning, and finally, investment denotes the desire in succeeding in learning the language (pp. 170-171). How students and teachers exercise these dimensions can bring profound differences in the results of language learning. When it comes to motivation in reading, improving students' engagement is considered a factor concerning developing reading performance and thus of language proficiency. In this sense, Anderson (2014) stressed that engaged readers are motivated; 
and for them to be motivated, there needs to be a teacher responsible for generating such engagements (pp.173-174). Teachers should go beyond the curriculum and think about the students' development and language attainment to develop motivation. For instance, allowing learners to make their own reading selections can make a difference in terms of engagement and enjoyment. Thus, the teacher should adapt the curriculum to the students' choices and find other ways to foster motivation.

Technology can promote motivation in the process of learning a language; it is a tool that increases students' learning by "providing them with realistic and motivating opportunities to practice their English" (Dudeney \& Hockly, 2008, p. 12). Concerning the use of the students' mobile devices in language teaching, they "can provide immediate feedback and thus provide continued motivation for those who are not motivated by traditional educational settings" (Geddes, 2004, as cited in Valk et al., 2010, p. 121). These advantages should be exploited in all linguistic skills. Hence, "technology growth is likely to make greater, rather than lesser, demands on people's reading abilities" (Grabe \& Stoller, 2013, p. xiv): and such demands may imply the development of engaged readers. From this perspective, English instructors ought to promote reading through technology; cell phones stimulate motivation by allowing learners to participate in less traditional reading activities. Moreover, teachers can motivate students in reading classes by integrating common mobile platforms such as social media and mobile applications.

There could be drawbacks related to using mobile devices in reading activities; the size of the phone and software limitations may reduce the applicability of the technology in the language classroom setting. Besides such technical difficulties, "Excessive cell phone use during class often leads students to engage in academic disengagement" (Lee et al., 2017, p. 360). Learners start multitasking by checking social media accounts and text messaging. Despite these potential distractions, "Mobile computing devices and the use of social media allow student interaction with content" (Gikas \& Grant, 2013, p. 25). When reading activities are the primary concern, cell phones can be a resource for students and an ally for professors, who should use mobile devices purposefully while providing precise directions to students and sufficient supervision.

\section{Design and Method}

This case study includes and systematizes teaching and learning experiences in an EFL context in Costa Rica and is grounded in a qualitative research methodology that employs an "open inquiry" view. It aims to provide detailed descriptions and interpretations of a phenomenon. It also allows for a cyclical analysis and provides an emic and etic perspective to present various viewpoints (Friedman, 2012, pp. 181-182). The participants were 15 second-year English language students from the Universidad 
Nacional, Brunca Extension, Pérez Zeledón Campus. The researcher also served as a practitioner-scholar, which is defined as "an individual who aspires to study problems of practice more comprehensively and systematically, allowing them to better understand the schools, districts, and other educational organizations within which they work" (Lochmiller \& Lester, 2017). Moreover, the data collection instruments and tools were an open-ended questionnaire and two focus group discussions administered to the students after a set of seven cell phone-based reading activities were implemented once a week for two months. Additionally, a reflective observation questionnaire gathered the professor's perceptions after each implementation activity.

First, cell phone-based activities were grounded on the idea that mobile technology can help English language students learn (Dudeney \& Hockly, 2008) by providing enjoyment (Ortega, 2013). These activities were heavily reliant on technology and positioned cell phones as the main instrument to access different platforms and applications. Moreover, the open-ended questionnaire focused on discovering the duration in which students use their mobile devices in the classroom, in which could lead to the understanding of the role that mobile devices actually play in their learning. Additionally, this instrument aimed to collect the students' perceptions at the end of the application of cell phone-based reading activities. In general, this questionnaire intended to gather data to assess cell phones' effectiveness as a learning tool and as motivators during reading activities.

Furthermore, this study utilized two focus groups to gather in-depth insights from students regarding the role of cell phone-based reading activities in developing motivation. These focus groups served as a follow-up instrument to the questionnaire; they allowed the researcher to access the students' perceptions in a less restricted environment. It also encouraged learners to inquire about aspects that were not clearly stated in their previous answers, or encouraging learners how to develop questions, make observations and judgements about important aspects of the questionnaire. Finally, the practitioner-scholar completed a reflective observation questionnaire designed to gather the instructor's perceptions of the role of cell phone-based activities in developing motivation during and after the implementation of the activities.

\section{Findings}

This section of the paper summarizes the results of the application of three instruments to gather information about the effectiveness of mobile technology in developing motivation in English language students.

In the questionnaire and focus groups, most of the students considered that technology, especially mobile technology, can help them learn English; they expressed that they use different applications and websites. When asked if they felt motivated to 
participate in cell phone-based classroom activities, the learners stated that they feel very motivated because they can use their mobile devices, which was and continue to be prohibited in most classes. Also, the attractiveness and newness of the activities motivated them to participate and complete the exercises. Some students stressed the importance of using a tool for learning that is personal and that they can have available all the time. Besides, the fact that some of the activities added a competitive element seemed to be a significant factor in promoting motivation. The activities considered to be the most interesting were Kahoot games, QR code treasure hunts, and online quizzes; the reasons were varied; some talked about the competitiveness and colorfulness of Kahoot while others expressed the importance of reviewing material and receiving instant feedback. Cell phones for academic purposes in class seem to be a useful tool for these students. The ubiquity of cell phones and the excitement that competitive and attractive activities brought to the learning environment helped learners interact with content, practice reading, and use their mobile devices.

In terms of the students 'perceptions of possible drawbacks brought by using cell phones in the classroom, they mention that social networks are distracting, but when using their mobile devices for learning, they forget about some distractions because they are using their devices for other purposes. Also, a vast majority of students agreed that a critical disadvantage does not lie in the mobile device itself, but the access to the Internet. According to the subjects, the campus has erratic and unreliable Internet service, which can be an obstacle when using the cell phone in class. Some students also remarked that it is difficult for professors to monitor students' actual academic use of their device during activities.

The practitioner-scholar assessed the students' reaction toward the implementation of cell phone-based reading activities; the investigator reported significant acceptance of mobile technology in the activities. The students reacted positively to the instructions and seemed willing to utilize their devices in class. During the activities, students did make effort to participate in them, and they fully cooperated when they had to complete the tasks. Moreover, there was a feeling of enjoyment, and the students asked many times if they could continue with a similar task. Concerning investment to succeed, there was a high level of desire to complete the activity and to improve their overall results.

\section{Discussion}

This section seeks to validate the research findings by comparing the data obtained to the existing theory. First, during the development of the reading activities, the professor and students engaged in what Hamilton (2015) called the "second model" of classroom technology. The teacher becomes a model and helps students to use and be 
in control of technology for learning. Hamilton (2015) also remarked that technology is essential due to the partaking properties it has. In this sense, students expressed that the mere fact that they were allowed to use their cell phones in class was an element that promoted learning. In many cases, technology in the classroom has been teacher controlled and handing students some of that control may help the learners to discover ideas and activate their schemata, as stated by Hamilton (2015).

Constantinescu (2007) expressed that reading is an active and interactive process that allows the use of several skills, strategies, and background knowledge. In this respect, cell phone-based reading activities promoted learning and allowed learners to engage with other linguistic skills. Additionally, students were able to complete and partake in problem-solving, and an element that helped students was the possibility to receive instant feedback in many activities, as supported by Valk et al. (2010). Such property of technology helped students to clarify knowledge and verify previously learned material. Thus, besides promoting motivation, technology provided a sense of novelty of how students accessed and interacted with reading materials. This finding connects with Nettelbeck (2005) who claimed that innovative measures need to be applied in the classroom to produce learning engagement to improve the range and depth of processing, which is unavailable to students in classrooms without technology use.

Kress \& Pachler (2007) exposed some challenges that technology may present when brought into the classroom. They highlighted some physical aspects of the devices, such as size and the amount of data that can be displayed and manipulated. Nonetheless, the students did not find such elements as challenges and focused mostly on the problems they have connecting to the Internet and agreed on the fact that social media can be tenting and keep them off task. Some physical characteristics of cell phones may have been surpassed today, allowing students to use their mobile devices just like a computer. However, new challenges may have arisen in terms of social media's obliquity and their notification in real-time.

Ortega (2013) related motivation to the intensity with which people want to learn, enjoyment or pleasure while learning, and their investment or desire to succeed. In this regard, the reading activities seem to have helped the learners mostly with the second aspect: enjoyment. The professor could verify that the students' engagement in the activities and their affinity with most of them. Technology seems to have had a central role in bringing enjoyment to the classroom; the reading activities prepared by the professor were designed around the use of different technologies. This fact supports Anderson's (2014) view of teachers' responsibility to promote engagement and motivation in the classroom.

Dudeney and Hockly (2008) asserted that technology affects language learning and motivation, and Grabe and Stoller (2013) contended that technology would require students to fulfill modern reading demands. In this sense, the set of reading activities 
seem to have helped learners to be exposed to the current reading requirements. The students could use their mobile devices to read and complete tasks; such activity is performed by English language readers every day as many favor electronic reading material and to complete everyday tasks on their cell phones. Thus, the reading activities allowed the learners to feel more engaged and motivated during the tasks. They could use their cell phones and other different technologies individually or with peers to learn, instead of using printed materials, which has been the norm in most reading courses.

\section{Conclusions}

The data obtained in this study has yielded information about the role of technology in the English language learning process in this particular group of learners. The students who participated in the focus groups and interviews established technology as a critical tool for learning. The diverse use of apps and websites and the easiness with which they access data and authentic materials place technology in the center of their exposure to the language. All the students acknowledged its importance and its many advantages. The use of mobile devices has gained popularity among teachers and students; in this specific study, most students considered its use to be advantageous in terms of portability, accessibility, and engagement.

Nonetheless, teachers must be cautious not to overuse this technology and plan carefully and accordingly, by developing clear objectives and maximizing its use. Besides, the use of cell phones enhances motivation in classes, increases student investment in the activities and learners showed a high level of effort, which boosted their reading skills. All the students also expressed that they enjoyed cell phone-based activities; there were positive feelings involved, which promoted learning and helped lower anxiety levels. According to the data collected, reading activities that integrate cell phones are engaging and add variety. Some informants remarked how the use of their mobile devices promoted diversity, which was refreshing and broke the monotony of using paper materials in their class.

The integration of mobile technologies into English teaching is an on-going process, yet there are many challenges to overcome. On a reflective note, the use of cell phones in the language classrooms may have many limitations, as experienced during the application of the reading activities. First, even when all the students who participated in the study had a smartphone, some of these devices showed limitations when accessing certain websites. For example, having reliable, high-speed internet service in different educational institutions in the country is very important. As per the changes required, there must be a shift in the way students and teachers view cell phones in classrooms. Some students claimed that they are still hesitant when using 
their devices since they have been accustomed not to use them in class. Professors need to be aware of the advantages that mobile technology can provide, especially in language classes in foreign contexts. Access to authentic materials, the variety of activities, and engaging dynamics are just some of the positive effects of mobile phones' inclusion in the teaching and learning environment. As new technologies emerge, new ways for improving reading may emerge; however, cell phones may be an essential device to exploit in English reading classrooms for many years to come. Nonetheless, English teachers need to be updated to explore new ways to reach the demands of learners who may need technology to develop their reading skills fully. 


\section{References}

Anderson, N.J. (2014). Developing engaged second language readers. In CelceMurcia, M., Brinton, D., \& Snow, M. A. (Eds.), Teaching English as a second or foreign language (pp. 168-188). Boston: National Geographic Learning.

Constantinescu, A. (2007). Using technology to assist in vocabulary acquisition and reading comprehension. The Internet TESL Journal, XIII(2). Retrieved from http:// iteslj.org/Articles/Constantinescu-Vocabulary.html

Dudeney, G., \& Hockly, N. (2008). How to teach English with technology. Harlow: Pearson/Longman.

Gass, S. M., \& Selinker, L. (2009). Second language acquisition: An introductory course. New York: Routledge.

Gikas, J., \& Grant, M. M. (2013). Mobile computing devices in higher education: Student perspectives on learning with cellphones, smartphones \& social media. The Internet and Higher Education, 19, 18 - 26. https://doi.org/10.1016/j. iheduc.2013.06.002.

Grabe, W., \& Stoller, F. L. (2013). Teaching and Researching Reading. London: Routledge.

Hamilton, B. (2015). Integrating technology in the classroom: Tools to meet the needs of every student. The USA: International Society for Technology in Education.

Kress, G. \& Pachler, N. (2007). Thinking about the ' $m$ ' in m-learning. In Pachler, N. (ed.), Mobile Learning: Towards a Research Agenda (pp. 7-32). London: WLE Centre, Institute of Education. Retrieved from https://www.researchgate.net/ publication/233981184_Thinking_about_the_'m'in_m-learning

Lee, S., Kim, M. W., Mcdonough, I. M., Mendoza, J. S., \& Kim, M. S. (2017). The Effects of Cell Phone Use and Emotion-regulation Style on College Students' Learning. Applied Cognitive Psychology, 31(3), 360-366. DOI: 10.1002/acp.332

Lochmiller, C. R., \& Lester, J. N. (2017). An introduction to educational research: Connecting methods to practice. Los Angeles: SAGE.

Friedman, D.A. (2012). How to collect and analyze qualitative data. In A. Mackey, \& S. M. Gass (Eds), Research Methods in Second Language Acquisition: A Practical Guide (180-200). Malden, MA: Wiley-Blackwell.

Nettelbeck, D. C. (2005). Computers, thinking and learning: Inspiring students with technology. Camberwell, Vic.: ACER Press. 
Ortega, L. (2013). Understanding second language acquisition. New York, NY: Routledge.

Valk, J., Rashid, A. T., \& Elder, L. (2010). Using mobile phones to improve educational outcomes: An analysis of evidence from Asia. The International Review of Research in Open and Distributed Learning, 11(1), 117-140. doi:10.19173/irrodl.v11i1.794

\section{Author}

${ }^{*}$ Roger Segura Arias is an academic in foreign languages and tourism at the Universidad Nacional de Costa Rica, Brunca Regional Headquarters, Pérez Zeledón Campus. He holds a Bachelor's Degree in Teaching English from the National University, a Licentiate's Degree in Teaching English from the Universidad Latina, a Licentiate's Degree in Applied Linguistics in English Teaching from the National University, a Master's Degree in Educational Sciences with an emphasis on Teaching at the San Isidro Labrador International University and a master's degree in Applied Linguistics with an emphasis on English for Specific Purposes from the School of Literature and Language Sciences, National University. His research areas are the use of technology in the English classroom, reflexive teaching and learning, and curricular design in foreign languages

ORCID: https://orcid.org/0000-0003-1553-3953

How to reference this article: Segura-Arias, R. (2021). The Role of Mobile Phones in Developing Motivation through Reading Activities in English Language Learners. GIST - Education and Learning Research Journal, 22(1), 7-19. https://doi.org/10.26817/16925777.823 